\author{
Arnaldo Cantani ${ }^{\star}$ \\ Pediatric Allergy and Immunology Division, Department of \\ Pediatrics Roma "La Sapienza" University, Italy \\ Dates: Received: 05 August, 2015; Accepted: 21 \\ November, 2015; Published: 23 November, 2015 \\ *Corresponding author: Arnaldo Cantani, Pediatric \\ Allergy and Immunology Division, Department of \\ Pediatrics Roma "La Sapienza" University, Italy; \\ E-mail: acantani13@gmail.com \\ www.peertechz.com \\ Keywords: Atopy; At-risk babies; Family history \\ Cutaneous and respiratory atopy; Inhalant and food \\ allergens; Preven $\neg$ tati 've measures
}

\section{Research Article \\ Role of Inhalant and Food Allergens in Child Sensitization: A Prospective Study in 176 Children}

\begin{abstract}
Background: The origin of atopic disease is poly factorial and the development of atopic manifestations appears to be linked to interactions between genetic and environmental factors. Such data seem to focus attention on the rising prevalence rates of atopic dermatitis, a common debilitating skin condition in infants and young children. They also often have asthma and/or allergic rhinitis.

Patients and Methods: The aim of the present study was to evaluate the rate of SPT (skin prick tests) and RAST response to Der $p$ in atopic children with AD. We have prospectively studied 176 children (93 males and 83 females) aged from 6 months to 7 years, and divided into four different groups, including controls. We studied also their family history in the accompanying parents Results. The data of the present study show that a significantly higher proportion of children with $A D$ have positive SPTs to Der $p$ than the controls, while RAST was positive in a lower proportion of babies. A significant part of the parents had a positive atopic history.

Conclusion: The early onset of such disorders in different parts of the world, and the strict connection between cutaneous and respiratory atopy appear of primary importance. Consequently, there is the clinical imperative that effective strategies should be adopted to amplify and improve preventative measures in at high-risk (HR) babies.
\end{abstract}

\section{Introduction}

Atopic dermatitis (AD), a major health concern in children, is characterized by a multifactorial pathogenesis in which a significant role is played by food allergy (FA) especially in infants [1]. In addition both diagnosis and treatment are difficult since the much in vogue diagnostic items, SPTs and RAST yield varying results in term of sensitivity, specificity, predicted positive and negative values [2,3]. The relationship between $\mathrm{AD}$ and FA has been established by doubleblind placebo-controlled food challenge tests (DBPCFC) and by significant improvement after appropriate elimination diet [2-4].

A substantial body of evidence suggests that among the various factors related to the indoor microenvironment which are able to aggravate $\mathrm{AD}$, the contact with inhalant allergens and in particular with house dust mite (Der p), as well as food allergens may play a critical role [5,6]. In fact, several reports appeared over the years linking initially pollen or mold exposure to flare of $\mathrm{AD}$ in affected patients [6-8].

\section{Role of inhalants in AD}

The relationship between $\mathrm{AD}$ and exposure to environmental allergens was first suggested in 1918 by Walker [9], who described several $\mathrm{AD}$ patients who experienced eczematous flaring following exposure to ragweed pollen and horse dander. Later, Cohen et al. [10], performed a very interesting experiment, which definitively showed that pollens can reach the cutaneous mast cells. In fact they published a study clearly documenting the rapid absorption of pollen through the respiratory mucosa and transit to cutaneous mast cells. Fifty normal control subjects were passively sensitized intracuta- neously with $0.2 \mathrm{ml}$ of serum from a ragweed allergic patient and $0.2 \mathrm{ml}$ of serum from a non-atopic control. Twenty-four hours later ragweed pollen was sprayed into both nostrils of the tested subjects. Interestingly, within 14-31 minutes (mean: 20 minutes), all study subjects developed a wheal-and-flare response appeared at the injection site but not the control site., thereby demonstrating that allergens, even if inhaled, reach the skin rapidly and then bind to IgE antibodies, thus triggering reactions of local anaphylaxis.

In the early 1950's, Tuft et al. [11,12], carried out an interesting set of experiments attempting to establish the pathogenic role of inhaled pollens in AD. The authors postulated that inhalation of pollen led to perspiration, which was linked to the development of itching and subsequent eczematous lesions. Subjects were dusted with a corn starch-iodine powder prior to inhaling a very small dose of dry ragweed pollen. After several minutes, a bluish colour change (showing that sweating had occurred) was noted about the neck and in the antecubital and popliteal fosse. The eczematous changes which developed persisted for several days [11]. Subsequently, Nilzen [13], reported the onset of eczematous changes in 4 out of $8 \mathrm{AD}$ patients following inhalation of an Alternaria spray. Hopkins et al. [14], observed a patient in whom the inhalation of a spray containing Alternaria spores was able to induce asthma and flares of eczema. Utilizing studies, similar to those previously described by Cohen et al. for ragweed [10], Tuft et al. performed inhalation studies with Alternaria. Similarly to previous studies utilizing ragweed pollen, sweating and pruritus developed within minutes, and over 1224 hours eczematous lesions developed in sensitized sites, which persisted for 4-5 days [15]. 
In 1961, Rajka reported that a great proportion of AD patients, with no clinical findings of respiratory allergy, presented with SPTs positive for several aeroallergens [16], thus suggesting that allergic reactions to airborne allergens could play a pathogenic role in some patients with AD [17]. Later, Chapman et al. [18], reported that adult patients with $\mathrm{AD}$ and without asthma have high levels of IgE and IgG antibodies towards the Der $\mathrm{p} 1$ allergen of Der $\mathrm{p}$ (the main allergen of Der p). These results tally well with SPTs positive for Der $\mathrm{p}$.

In 1982, Mitchell et al. [19], first suggested that even contact with dust mite may provoke skin lesions in patients with $\mathrm{AD}$. In 10 adult patients with $\mathrm{AD}$ an eczematous reaction was provoked 48 hours after application, with modified PT (patch tests) on mildly abraded skin, an aqueous Der p extract. The PT was positive only in AD patients with positive SPT to Der $p$. In addition, $4 / 6$ atopic adults not suffering from AD had PT positive response. Biopsies of the positive test sites revealed an eosinophil, peripheral blood mononuclear cell (PBMCs) and neutrophil infiltration with a significant increase in the number of basophils and eosinophils. Mitchell et al. speculated that this kind of infiltrate could be a variation of the delayed-type hypersensitivity possibly linked to a basophil chemotactic factor released by $\mathrm{T}$ cells.

Subsequently [20], eczematous lesions on not manipulated skin appeared in 3/17 patients with AD 42-78 hours after application of a Der p lyophilized commercial preparation to the PT site. At variance with Mitchell et al. results [19], Reitamo et al. reported positive PTs also in patients with negative SPT for Der p. Biopsies of the positive test sites revealed an eczematous reaction with a cell infiltrate similar to that described in $\mathrm{AD}$ by other studies [21], i. and. T lymphocytes, Langerhans cells (LCs), mast cells, eosinophils and basophils. Again at variance with Mitchell et al. results [19], there was a small proportion of mast cells and basophils, usually $5-10 \%$ of the total number of infiltrating cells [20].

Gondo et al. [22], in 1986, have reproduced typical AD lesions on non-manipulated skin in $4 / 13$ adults with $\mathrm{AD}$ by applying twice a day for 2-5 days an ointment containing Der $\mathrm{f}$ (Dermatophagoides farinae). These authors also demonstrated the penetration of Der $\mathrm{f}$ (which was linked with ferritin) into the stratum corneum, the epidermis and the dermis.. In this study, the lesions were present only in skin typical areas and only following a mild skin abrasion before PT 'application. The authors hypothesized that eczema, rather than being a primary eruption, is likely to be the result of various repeated stimuli combining both type I and type IV immune reaction with a primary irritant response to a combination of physical, chemical, and mechanical factors, including scratching due to persistent itching. In this study, following the percutaneous challenge with Der $\mathrm{p}$ allergen, a type I reaction occurred in the patients, while an eczematous type IV reaction occurred on repeated challenges.

Norris et al. [23], in 1988 applied $1 \mathrm{ml}$ of a SPT solution containing Der $\mathrm{p}$ on the unmanipulated antecubital or popliteal skin of atopic adults with or without $\mathrm{AD}$ for 5 days. Worsening of the skin lesions occurred in $1 / 3$ patients with $\mathrm{AD}$ and positive SPT response to Der $p$. Application of Der $p$ solution to which patients with AD were negative on SPTs. produced no significant local reaction. Adinoff and Clark et al. [24-26], elicited delayed cutaneous response in 18 patients with $\mathrm{AD}$ applying various aeroallergens including Der $\mathrm{f}$ extracts (20 $\mathrm{w} / \mathrm{v}$ in $50 \%$ glycerin), on clinically uninvolved and not manipulated skin. PTs were positive to a variety of allergens including Der $\mathrm{p}$, animal danders, pollens and molds in about $25 \%$ of patients with positive SPTs to these allergens. These investigators have reported that avoidance of aeroallergens that elicited an eczematous reaction at PT sites or cause immediate hypersensitivity reactions resulted in marked improvement or remission of $\mathrm{AD}$ in all patients. However, Henderson et al. [27], found that the temporal variations of Der $p$ ambient concentrations they observed were not related to a variation of the clinical course of AD. The authors suggested, based on their findings, that a delayed-type pathogenesis might play a role in $\mathrm{AD}$ Very stimulating are the Bruynzeel-Koomen et al. [28], results. They have shown $70 \%$ positive PT response, applying Der $\mathrm{p}$ (and pollen allergens) on the back of $15 \mathrm{AD}$ adult patients, previously removing the superficial stratum corneum by 15 consecutive applications of adhesive tape. No positive responses were found in atopic patients without $\mathrm{AD}$ or in controls. Positive PT reactions were not found in normal controls or atopic patients without AD. These PTs caused eczematous lesions. Analysis of the cellular infiltrate demonstrated an influx of eosinophils into the dermis, starting within 2-6 hours of PTs. Immunostaining with antibodies against granular constituents of the eosinophils revealed that infiltrating cells were in an activated state and had lost part of their granular contents. At 24 hours eosinophils also appeared in the epidermis. Histologically, a predominance of $\mathrm{T}$ cells of the helper/inducer phenotype have been observed. Activated eosinophils which have lost their granular contents are also seen in these lesions. Positive reactions were similar clinically to AD lesions (erythema with infiltration and/or papule).. Several eosinophils were activated and degranulated as shown by the presence of ECP (Eosinophil Cationic Protein) and EXP (Eosinophil X Protein). Electron microscopy showed that at 24 hours the number of activated eosinophils was reduced and some were present also in the epidermis but not activated and in close contact with LCs, suggesting a cell-cell interaction. At 24-48 hours in the dermis were observed also T cells, LCs, indeterminate cells and mast cells. To explain these findings, Bruynzeel-Koomen et al. have analyzed the pathogenesis of $\mathrm{AD}$ as based on the presence of IgE on LCs [29]: It has been suggested that, immediately after PTs, some allergens once penetrated into the epidermis, bind to IgE molecules on mast cells in the dermis and induce an immediate type reaction; mast cells release ECF and some of the infiltrating eosinophils become activated. Other allergens in the epidermidis, bind to IgE molecules on LCs presenting allergens to T cells, thus triggering the test positivity after 24-48 hours [30]. The above results strongly suggest an active role for eosinophils in $\mathrm{PT}$ reactions to inhalant allergens in patients with $\mathrm{AD}$ Bieber et al. [31], have demonstrated that epidermal LCs binding to IgE express the high affinity receptor for the Fc fragment of IgE (FceRI). Studies with CD1+: have shown that both receptors are implicated, FceRI and FceRII. These findings open new perspectives in the LC functional role as antigen-presenting cells especially in patients with widespread involvement, skin-derived IL4 might affect B-cell switching to IgE production in skin-draining lymph nodes [32], with the obvious cooperation of $\mathrm{T}$ lymphocytes in the cognate machinery, thus contributing to the chronic synthesis of IgE antibodies. 


\section{Role of food allergens}

Since 1936 FA was suggested as a contributing factor in AD. Grulee and Sanford demonstrated that cow's milk (CM) feedings predisposed to the development of $\mathrm{AD}$ since breast-fed babies had a prevalence of eczema seven times lower than that of bottle-fed children [33]. Later on, Glaser et al. $[34,35]$, have reported that children with a family history of allergy and soy formula fed during the first six months of life, also excluding egg and beef had 75\% less eczema and asthma in comparison with CM-fed children It was demonstrated a marked improvement of $\mathrm{AD}$ in 21 2-8-yr-old children receiving a CM- and egg-free diet: 14 children responded more favorably to the antigen-avoidance diet employing a soy formula as CM-substitute, whereas only one had a more favorable response to a not CM- and egg-free diet [4].

In a study by Sampson et al. [36], and one performed by our Department [37], the AD children were subjected to elimination diets and subsequent food reintroduction. A clear correlation was demonstrated between certain foods (in order of frequency (CM, egg, wheat and fish) and the onset and worsening of $\mathrm{AD}$. A further impetus stems from the previous study of aeroallergens eliciting eczematous reactions in the skin, as seen in atopy PTs, thus denoting that protein allergens from various foods can also enter into and through the skin in sufficient amounts and in immunogenic form [38]. This may be exploited for diagnostic purposes by rubbing foodstuff over the skin, a kind of prick by prick method [39], and obvious in protein contact urticaria $[40,41]$.

Aim of the present study was to evaluate the rate of SPT (skin prick tests) response to Der $\mathrm{p}$ in atopic children with $\mathrm{AD}$.in prospectively studied children with in progress or previous AD.

\section{Patients and Methods}

\section{Patients}

We have prospectively studied 176 children (93 males and 83 females), ( $p=0.0014$ ) aged from 6 months to 7 years (median age of 3 years and 11 months), who attended the Allergy and Immunology Division, Department of Pediatrics, University of Rome "La Sapienza" . The children were divided into 4 groups:: group 1 included 31 children who suffered from $\mathrm{AD}$ at the enrollment; group 2 included 23 children in actual remission, in a stable phase without acute flares of eczema; group 3 included 25 atopic children with asthma and/or rhinitis who never suffered from AD; group 4 comprised 97 healthy children recruited during the same period from our outpatient clinic with no history of atopy of comparable age and sex formed the control group We have studied the family history asking whether their accompanying parents had atopic diseases The diagnosis of AD was made according to Hanifin and Rajka criteria [42]. The severity score of AD was evaluated according to the SCORAD index [43], informed consent was obtained from parents of each child.

\section{Methods}

Appropriate emergency equipment and medications were available on site. Parents were required to discontinue antihistamine drugs and topical steroids at least 2 weeks before the application of the SPTs. Skin testing was done at baseline by the prick method on the volar surface of the forearm by a doctor trained in allergy with the co-operation of a qualified nurse. The skin was marked with a ballpoint pen for the allergens to be tested. The babies were tested with: histamine hydrochloride $(1 \mathrm{mg} / \mathrm{ml})$ as a positive control and isotonic saline as a negative control. We continued with a battery of food and inhalant allergens, including: whole CM protein, casein, lactalbumin, egg, fish, wheat, soy, Dermatophagoides pteronyssinus, (Der p), Alternaria alternata, Lolium perenne, Olea europea and Parietaria officinalis (SARM, Roma, Italy). The diagnostic extract of each individual allergen was placed on the volar surface of the forearm as drops through which the skin was superficially pricked with a straight pin. A new pin was used for each prick test and then discarded, and the drop of the extract was then wiped off about one minute after the prick [44], SPTs were read at 20 minutes and considered positive as follows:

+ When the wheal was the half of the histamine wheal;

++ When the wheal was equal to the histamine wheal;

+++ When the wheal was two-fold the histamine wheal;

++++ When the wheal was more than two-fold the histamine wheal [45].

We took for positive only children with a +++ or ++++ reaction, that is a wheal $33 \mathrm{~mm}$ with an area $=7 \mathrm{~mm} 2$ (cut-off) so we considered as positive only the children with a mean wheal diameter of $3 \mathrm{~mm}$ or larger than the negative (saline) control. A positive (histamine) control was performed to ensure the absence of any antihistamine drug interference [46].

\section{Specific IgE}

Determination of specific IgE antibodies was performed by radioallergosorbent test (Phadezym RAST, Pharmacia Diagnostics).

RAST results are expressed in $»$ RAST Units $«(P R U=$ Phadebas Rast Unit) as follows:

1 st class $=$ IgE levels $<0,35 \mathrm{IU} / \mathrm{ml}$,

2nd class $=\mathrm{IgE}$ levels $>0,35 \mathrm{IU} / \mathrm{ml}$ and lesser than $0,7 \mathrm{IU} / \mathrm{ml}$,

3 rd class $=\mathrm{IgE}$ levels between $0,7 \mathrm{IU} / \mathrm{ml}$ and $17 \mathrm{IU} / \mathrm{ml}$,

4th class $=\mathrm{IgE}$ levels higher than $17 \mathrm{IU} / \mathrm{ml}$.

Only RAST results > 0,35 IU/ml were considered positive Statistical analysis. The statistical calculations were performed using the X2 test.

\section{Results}

SPTs for Der p were positive in 18/31 (58\%) group 1 children with a high SCORAD index, in 13/23 (56.5\%) group 2 children with a low SCORAD index, in 14/25 (56\%) group 3 children and in no control child $(\mathrm{p}=0.0001)$. Both group 3 and group 4 had no SCORAD index. Children with in progress or previous AD (groups 1 and 2) had in addition, compared to group 3 children SPTs positive for CM in $19 / 54$ cases $(35 \%)$ versus $1 / 23(4 \%)(p=0.0047)$, for egg in $19 / 54$ $(35 \%)$ versus $3 / 23(13 \%)(\mathrm{p}=0.049)$ and for wheat in $7 / 54(12.9 \%)$ versus $2 / 23$ (9\%) (NS). 
No control child presented with positive SPTs, neither for inhalant, nor for food allergens RAST results were positive for Der $\mathrm{p}$ in 12/31 (38.7\%) group 1 children, in 10/23 (43.5\%) group 2 children, in $9 / 25$ (36\%) group 3 children and in no control child.

As regards the reciprocal correlations of SPTs and RAST results for Der $\mathrm{p}$, this was possible in the 51 children with $\mathrm{AD}$ of groups 1 and 2 with different clinical characteristics. The larger subpopulation was of 27/51 (52.9\%) children with positive SPTs and RAST for Der p; 18/51 (35.3\%) children had positive SPTs and negative RAST; 4/51 (7.8\%) children had negative SPTs and positive RAST and 2/51 (3.9\%) children had negative SPTs and RAST.

In group 3, 15/25 children had SPTs and/or RAST positive for Der $\mathrm{p}$ and $4 / 25$ with positive SPTs had negative RAST, while $6 / 25$ children had SPTs and/or RAST negative except one with only SPTs positive for Der $\mathrm{p}$.

In total, $64 / 76(84.2 \%)$ children had positive SPTs, while 46/76 (60.5\%) had a positive RAST ( $\mathrm{p}=0.0001$ ) Thirty-nine out of the 51 children of the groups 1 and $2(76.5 \%)$ and $9 / 25$ children of the group $3(36 \%)$ had a positive family history of atopy $(\mathrm{p}=0.0006)$, while only $4 / 97$ controls had a positive family history of atopy (NS).

\section{Discussion}

The data in the present study demonstrate that a significantly higher proportion of children still suffering from or previously affected with AD (groups 1 and 2) had positive SPTs for Der $p$ than the atopic children with asthma and/or rhinitis who have never suffered from $\mathrm{AD}$ (group 3$)(\mathrm{p}<0.001)$ as expected, and compared to controls (group 4). In addition, children of groups 1 and 2 had many SPTs positive for foods $(45 / 56=80.4 \%)$ as a part of their polysensitization, while in group 3 children the figures were $6 / 25=24 \%(p=0.001)$. Hence, we can confirm that;

1. FA is much more frequent in children with $\mathrm{AD}$ compared to children with respiratory allergy, and

2. That SPTs recognize much more children than RAST, a result equally valid for children with $\mathrm{AD}$ and with respiratory allergy.

Strangely enough, a high proportion of children with present or past $\mathrm{AD}$ had a significantly positive family history of atopy $(76.5 \%)$, compared to children with respiratory allergy $(36 \%)(p=0.0006)$, because in a study in preparation on 289 asthmatic children $56.4 \%$ of parents were atopic. Therefore, in this study AD seems to be a major determinant of atopy Recent evidence suggests that exposure to high levels of allergen during early life might contribute to the increasing prevalence of allergic disease. A high incidence of Der $\mathrm{p}$ allergen was found in early infancy as a risk factor for developing AD [47]. Mite allergy in children reaches a very high incidence in 10 studies comprising 12072 children aged 1-16 years [48-57]: the mean sensitization to mites was $18.7 \%$ ( $\min 1,7 \%$, $\max 42.8 \%$ ). Although these incidences were established with different laboratory methods, they may serve as a reference, especially considering the number of the children investigated.

Several studies strongly suggest that Der $\mathrm{p}$ exposure can trigger eczematous skin lesions. Der $\mathrm{p}$ is very potent mite, having 9 different allergens $[58,59]$, and can play a role in the pathogenesis of $\mathrm{AD}$ even by inhalation [60]. Mitchell et al. first suggested that the skin lesions of AD could be provoked even by contact with Der $p$ [19]. The most significant data of Der p sensitization in AD patients can be so summarized:

- clinical and epidemiological studies demonstrate that aeroallergen contact may aggravate $\mathrm{AD}[19,60]$;

- allergen-specific T cells are isolated in a great number in skin sites [25];

- a part of these T cells show to be Th2 cells, especially if isolated from bloodstream, with values varying between 11 and $70 \%$ and more often CD8+ cells are observed as very reduced in number [61];

- these T cells, deriving either from bloodstream or skin, are able to trigger IgE switch from B lymphocytes, probably within regional lymph nodes by virtue of LCs [62], thus triggering the chronic IgE synthesis [63], which is associated with current or later atopic disease [64];

- It has been suggested that immediately after PTs, some of the allergens penetrate the epidermis, bind to the IgE molecules on mast-cells in the dermis and induce an immediate type reaction; mast cells release ECF and some of the infiltrating eosinophils become activated [25].

- the presence of Der p-specific cells and Th2-like T cells in skin lesions is not always correlated with serum Der p-specific IgE antibodies or with total IgE elevated concentrations [61,65];

- the scarce correlation is also appreciated about interleukin (IL) levels, for example IL4 [61];

- however, subjects with Der p-specific IgE antibodies suffer from more severe lesions compared to subjects with PT positivity [66];

- It is therefore likely that anti-Der p 1 Th2-like responses are limited to initial lesions [18], nonetheless even if further studies are needed to clarify whether such events are specific for $\mathrm{AD}$, it is undisputable that they effectively demonstrate the role played by mites in $\mathrm{AD}$ pathogenesis.

We may speculate that in children with $\mathrm{AD}$ and either positive PTs and skin prick tests the allergen makes contact with IgE+-LCs which, in turn, present allergen to skin T-cells so inducing the late response [30]. Moreover the important role of skin T-cell in inducing the PT test reaction has been emphasized by a recent work [67], which indicated that activated skin T-cells of a PT-biopsy were of Th2 phenotype and allergen specific Mite allergy has in addition a very early onset. In the study of Huang et al. [47], a significant proportion of babies had asthma and/or $\mathrm{AD}$ by age 3 . In a recent meta-analysis, in the first year of life, there is the onset of $\mathrm{AD}$ in $79,8 \%(60,2 \%$ to $100 \%$ ) in the second year in $11.2 \%$ (7 to $16.6 \%$ ) of children. Asthma starts in the first year of life in $28,1 \%$ (23 to $33 \%$ ) and in the 2 nd in $42,6 \%$ (32 to $43 \%$ ) of children [22]. As regards AD, more babies are 
affected in the first year, during which there is also a great prevalence of food allergy [68]. Atopy is inherited [69,70], and the most exposed babies have one or both parents affected from atopy [71]. A recent study in children with $\mathrm{AD}$ and CMA found a positive association with HLA-DQ, and that DQ+ children had a prevalence of humoral rather than cellular responses [72]. There is a linkage between IgE responses underlying asthma and rhinitis and chromosome 11q [73], however asthma is linked to chromosome 6p21.3 through TNF-b polymorphism [74].

To face this panorama, we should recur to primary prevention, which includes a chain of measures set forth in order to prevent the "allergy march". The possibility of preventing atopic diseases in HR babies has been confirmed by several groups of investigators and we point out that in order to prevent atopic diseases in HR babies they should be subjected not only to dietary measures, but also to environmental guidelines. We stress that children with $\mathrm{AD}$ may have inherited independently not only the proclivity to occasion IgE antibodies ("atopic status"), but even xerosis which augments the skin susceptibility to environmental allergens and irritants. This is an attempt of understanding why hypersensitivity to the same allergen provokes $\mathrm{AD}$ in someone and asthma in others. Therefore, preventing specifically early exposure in addition to the subsequent sensitization, is a very crucial step for reducing the increasing prevalence of allergic disease, especially for HR babies and young infants. A note of caution: prevention should begin at the moment of birth: we have stressed the negative effects of the maternity wards.

\section{References}

1. Businco L, Ferrara M, Cantani A (1991) Food allergy and atopic dermatitis. Pediatr Allergy Immunol 2: 18-22.

2. Sampson HA, Albergo RA (1984) Comparison of results of skin test, RAST, and double blind, placebo-controlled food challenge in children with atopic dermatitis. J Allergy Clin Immunol 74: 26-33.

3. Cantani A, Arcese G, Serra A, Lucenti P (1995) Results of skin test, RAST, and food challenges in children with atopic dermatitis associated with food allergy. Paediatr Paedol 30: 113-117.

4. Atherton DJ, Sewell M, Soothill JF, Wells RS, Chilvers CE (1978) A double blind controlled cross-over trial of an antigen-avoidance diet in atopic eczema. Lancet i: 401-403.

5. Tuft L (1949) Importance of inhalant allergens in atopic dermatitis. J Invest Dermatol 12: 211-219.

6. Peck SM, Salomon G (1933) Eczema of infancy and childhood: contacts as etiologic agents, with particular reference to feathers. Am J Dis Child 46 : 1308-1328.

7. Hill LW (1937) Sensitivity of house dust and goose feathers in infantile eczema: the role of specific allergens. J Allergy 1937; 9: 37-47.

8. Cazort AG (1936) The house dust antigen in allergy. South MJ 29: $1022-$ 1026.

9. Walker IC (1918) Causation of eczema, urticaria, and angioneurotic edema by proteins other than those derived from foods. JAMA 70: 897-900.

10. Cohen MB, Ecker EE, Breribart JR, Rudolph JA (1930) The rate of absorption of ragweed pollen material from the nose. J Immunol 18: 419-425.

11. Tuft L, Tuft HSW, Heck VM (1950) Atopic dermatitis. II. Role of the sweating mechanism. J Invest Dermatol 15: 333-337.

12. Tuft L, Heck VM (1952) Studies in atopic dermatitis. IV. Importance of seasonal inhalant allergens, especially ragweed. J Allergy 23: 520-540.
13. Nilzen A (1958) Experimental background of some abnormal vascular reactions in atopic dermatitis and significance of skin tests in man. Third International Congress of Allergology. Paris 635.

14. Hopkins JG, Kersten BM, Benham RW (1930) Sensitization of saprophytic fungi in a case of eczema. Proc Soc Exp Biol Med 27: 432-434.

15. Tuft L, Tuft HSW, Heck VM (1950) Atopic dermatitis. I. An experimental clinical study of the role of inhalant allergens. J Allergy 21: 181-186.

16. Rajka G (1982) Studies in hypersensitivity to molds and staphylococci in prurigo Besnier (atopic dermatitis). Acta Derm Venereol 1-139.

17. Rajka G (1961) Prurigo Besnier (atopic dermatitis): with special reference to the role of allergic factors. Acta Derm Venereol 41: 363-395.

18. Chapman MD, Rowntree S, Mitchell EB, Di Prisco de Fuenmajor MC, PlattsMills TAE (1983) Quantitative assesment of $\lg G$ and $\operatorname{lgE}$ antibodies to inhalant aller-gens in patients with atopic dermatitis. J Allergy Clin Immunol 72: $27-33$.

19. Mitchell EB, Crow J, Chapman MD, Sckhminder SJ, Pope FM, et al. (1982) Basophils in allergen-induced patch test sites in atopic dermatitis. Lancet 1 : 127-130.

20. Reitamo S, Visa K, Kähönen K, Käyhkö K, Stubb S, et al. (1986) Eczematous reactions in atopic patients caused by epicutaneous testing with inhalant allergens. Br J Dermatol 114: 303-309.

21. Leung DYM, Bhan AK, Schneeberger EE, Geha RS (1983) Characterization of the mononuclear cell infiltrate in atopic dermatitis using monoclonal antibodies. J Allergy Clin Immunol 71: 47-56.

22. Gondo A, Saeki N, Tokuda Y (1986) Challenge reactions in atopic dermatitis after percutaneous entry of mite antigen. Br J Dermatol 115: 485-493.

23. Norris PG, Schofield O, Camp RDR (1988) A study of the role of house dust mite in atopic dermatitis. $\mathrm{Br} \mathrm{J}$ Dermatol 118: 435-440.

24. Adinoff AD, Tellez P, Clark RAF (1988) Atopic dermatitis and aeroallergen contact sensitivity. J Allergy Clin Immunol 81: 736-742.

25. Clark RAF, Adinoff AD (1989) Aeroallergen contact can exacerbate atopic dermatitis: patch tests as a diagnostic tool. J Am Acad Dermatol 21: 863-869.

26. Clark RAF, Adinoff AD (1989) The relationship between positive aeroallergen patch test reactions and aeroallergen exacerbation of atopic dermatitis. Clin Immunol Immunopathol 53: 132-140.

27. Henderson AJW, Kennedy CTC, Thompson SJ, Carswell F (1990) Temporal association between Der $\mathrm{p}$ exposure, immediate hypersensitivity and clinical severity of eczema. Allergy 45: 445-450.

28. Bruynzeel-Koomen CAFM, Van Wichen DF, Spry CJF, Venge P, Bruynzeel PLB (1988) Active participation of eosinophil in patch test to inhalant allergens in patients with atopic dermatitis. Br J Dermatol 118: 229-238.

29. Bruynzeel-Koomen CAFM, Bruynzeel PLB (1988) A role for IgE in patch test reactions to inhalant allergens in patients with atopic dermatitis. Allergy 43 : $15-21$.

30. Mudde GC, Van Reijsen FC, Boland GJ, De Gast GC, Bruijnzeel PLB, et al. (1990) Allergen presentation by epidermal Langerhans' cells from patients with atopic dermatitis is mediated by IgE. Immunology 60: 335-341.

31. Bieber T1, de la Salle H, Wollenberg A, Hakimi J, Chizzonite R, et al. (1992) Human epidermal Langerhans cells express the high affinity receptor for immunoglobulin E (FceRI). J Exp Med 175: 1285-1290.

32. Bos JD, Kapsenberg ML, Sillevis Smitt JH (1994) Pathogenesis of atopic eczema. Lancet 343: 1338-1341.

33. Grulee CG, Sanford HN (1936) The influence of breast and artificial feeding on infantile eczema. J Pediatr 9: 223-225.

34. Glaser J, Johnstone DE (1953) Prophylaxis of allergic disease in the newborn. J Am Med Assoc 153: 620-622.

35. Glaser J (1955) The prophylaxis of allergic disease with special reference to the newborn infant. NY State J Med 55: 2599-2605. 
36. Sampson HA, McCaskill CC (1985) Food hypersensitivity and atopic dermatitis: Eval-uation of 113 patients. J Pediatr 107: 669-675.

37. Businco L, Businco E, Cantani A, Galli E, Infussi R, et al. (1982) Results of a milk and/or egg free diet in children with atopic dermatitis. Allergol Immunopathol 10: 283-288.

38. Saloga J, Knop J (2000) Does sensitization through the skin occur? Allergy 55: 905-909.

39. Cantani A, Micera M (2006) The prick by prick test is safe and reliable in 58 children with atopic dermatitis and food allergy Eur Rev Med Pharmacol Sci 10:115-120.

40. Acciai MC, Brusi C, Francalanci S, Gola M, Sertoli A (1991) Skin tests with fresh foods. Contact Dermatitis 24: 67-68.

41. Cantani A (1997) Allergic reaction to inadvertent peanut contact in a child. Allergy Asthma Proc 18: 323-326.

42. Hanifin JM, Rajka G (1980) Diagnostic feature of atopic dermatitis. Acta Derm Venereol 92: 44-47.

43. Stalder JF, Taïeb A, Atherton DJ (1993) Severity scoring of atopic dermatitis the SCORAD index. Dermatology 186: 23-31.

44. Pepys J (1975) Skin testing. Br J Hosp Med 14: 412-417.

45. Dreborg S, Backman A, Basomba A (1989) Skin tests used in type I allergy testing Position paper. Sub-Committee on Skin Tests of the European Academy of Allergology and Clinical Immunology. Allergy 44: 1-59.

46. Aas K, Belin L (1974) Suggestions for biologic qualitative testing and standardization of allergen extracts. Acta Allergol 29: 238-240.

47. Huang JL, Chen CC, Kuo ML, Hsieh KH (2001) Exposure to a high concentration of mite allergen in early infancy is a risk factor for developing atopic dermatitis: A 3-year follow-up study. Pediatric Allergy Immunol 12: 1116.

48. Del Rio NB, Barragan MM, Sienra MJ (1994) Comparative study of three in vitro methods for determination of specific IgE antibody in allergic infants. Ann Allergy 72: 94A.

49. Bidat E, Eliazord G, Gallet JP (1991) Pensez à l'allergie aux blattes chez l'enfant (lettre). Arch Fr Pédiatr 48: 513.

50. Tariq SM, Matthews SM, Stevens M, Hakim EA (1996) Sensitization to Alternaria and Cladosporium by the age of 4 years. Clin Exp Allergy 26: 794798.

51. Karachaliou FH, Panagiotopoulou K, Manousakis M, Sinaniotis K, Papageorgiou F (1995) Month of birth, atopic disease, and sensitization to common aeroallergens in Greece. Pediatric Allergy Immunol 6: 216-219.

52. Remes ST, Korppi M (1996) Asthma and atopy in schoolchildren in a defined population. Acta Pædiatr 85: 965-970.

53. Peruzzi M, De Luca M, De Martino M, Vierucci A (1993) Allergia alle Blattidae in età pediatrica. Riv Ital Pediatr 19: 515-551.

54. von Mutius E, Martinez F, Fritzsch C, Nicolai T, Röll G, et al. (1994) Prevalence of asthma and atopy in two areas of West and East Germany. Am J Respir Crit Care Med 149: 358-364.

55. Bräbäck L, Breborowicz A, Dreborg S, Knutsson A, Pieklik H, et al. (1994) Atopic sensitization and respiratory symptoms among Polish and Swedish school children. Clin Exp Allergy 24: 826-835.

56. Riikjärv MA, Julge K, Vasar M, Bråbäck L, Knutsson A, et al. (1995) The prevalence of atopic sensitization and respiratory symptoms in Estonian schoolchildren. Clin Exp Allergy 25: 1198-1204

57. Koivikko A (1974) Childhood asthma in Finland. A survey of 559 patients. Acta Allergol 29: 30-72.

58. Stewart GA, Thompson PJ (1996) The biochemistry of common aeroallergens. Clin Exp Allergy 26: 1020-1044.

59. Metcalfe DD, Astwood JD, Townsend R, Sampson HA, Taylor SL, et al. (1996) Assessment of the allergenic potential of foods derived from genetically engineered crop plants. Crit Rev Food Sci Nutr 36: S165-S186.

60. Platts-Mills TAE, Chapman MD, Mitchell B, Heymann PW, Deuell B (1991) Role of inhalant allergens in atopic eczema. In Ruzicka T, Ring J, Pryzbilla B, eds. Handbook of atopic eczema. Berlin: Springer-Verlag 192-203.

61. Virtanen T, Maggi E, Manetti R, Piccinni MP, Sampognaro S, et al. (1995) No relationship between skin-infiltrating Th2-like cells and allergen-specific IgE response in atopic dermatitis. J Allergy Clin Immunol 96: 411-420.

62. Tanaka Y, Anan S, Yoshida S (1990) Immunohistochemical studies in mite antigen induced patch test sites in atopic dermatitis. J Dermatol Sci 1: 361 368.

63. Sager N, Fedmann A, Schilling G, Kreitsch P, Neumann C (1992) House dust mite-specific $T$ cells in the skin of subjects with atopic dermatitis: Frequency and lymphokine profile in the allergen patch test. J Allergy Clin Immunol 89: 801-810.

64. Sigurs N, Hattevig G, Kjellman B, Kjellman N-IM, Nilsson L, et al. (1994) Appearance of atopic disease in relation to serum IgE antibodies in children followed up from birth for 4 to 15 years. J Allergy Clin Immunol 94: 757-763.

65. Del Prete G (1994) Th1 and Th2 cells in atopy. EOS 14: 15-19.

66. Imayama S, Hashizume T, Miyahara H, Tanahashi T, Takeishi M, et al. (1992) Combnation of patch test and IgE for dust mite antigen differentiates 130 patients with atopic dermatitis into four groups. J Am Acad Dermatol 27 : 531-538.

67. van Reijsen FC, Bruijnzeel-Koomen CA, Kalthoff FS, Maggi E, Romagnani S, et al. (1992) Skin-derived aeroallergen-specific T-cell clones of Th2 phenotype in patients with atopic dermatitis. J Allergy Clin Immunol 90: 184193.

68. Cantani A (1999) The growing genetic links and the early onset of atopic diseases in children stress the unique role of the atopic march: a metaanalysis. J Invest Allergol Clin Immunol 9: 314-320.

69. Blumenthal MN, Amos DB (1987) Genetic and immunologic basis of atopic responses. Chest 91: 176S-184S.

70. Marsh DG, Meyers DA, Bias WB (1981) The epidemiology and genetics of atopic allergy. N Engl J Med 305: 1551-1559.

71. Dold S, Wjst M, von Mutius E, Reitmer P, Stieper E (1992) Genetic risk for asthma, allergic rhinitis, and atopic dermatitis. Arch Dis Child 67: 1018-1022.

72. Camponeschi B, Lucarelli S, Frediani T, Barbato M, Quintieri F (1997) Association of HLA-DQ antigen with cow milk protein allergy in Italian children. Pediatr Allergy Immunol 8: 106-109.

73. Cookson WOCM, Faux JA, Sharp PA, Hopkin JM (1989) Linkage between immunoglobulin $\mathrm{E}$ responses underlying asthma and rhinitis and chromosome 11q. Lancet 1: 1292-1295.

74. Cookson WOCM, Moffatt MF (1996) Asthma and tumor necrosis factor polyphormism. Hum Immunol 47: 160.

Copyright: () 2015 Cantani A . This is an open-access article distributed under the terms of the Creative Commons Attribution License, which permits unrestricted use, distribution, and reproduction in any medium, provided the original author and source are credited. 